\title{
Resource Use Efficiency in Part-time Food Crop Production: The Stochastic Frontier Approach
}

\author{
*11M.Y Amodu, ${ }^{2}$ J.O. Owolabi and ${ }^{1}$ S.S Adeola \\ ${ }^{1}$ Department of Agricultural Economics and Rural Sociology, Ahmadu Bello University, Zaria, Nigeria \\ ${ }^{2}$ Agricultural Engineering Department, Faculty of Engineering, Institute of Agric. Research, ABU-Zaria \\ [*Corresponding author's e-mail:mikeamodu@yahoo.com; 07039056317]
}

\begin{abstract}
In this paper, stochastic frontier production model was used to analyze the resource use efficiency of part-time food crop farmers in Idah, North Central Nigeria. The result shows that farm size, labour and planting materials are significant determinants of farm output in part-time food crop farming. Analysis of inefficiency factors reveal the significant inefficiency variables to include; level of education, household size and farming experience. The result also shows that over $72 \%$ of part-time farmers were above average in resource use efficiency; maximum efficiency is 0.98 , while minimum efficiency is 0.36 with mean efficiency of 0.65 . The study also revealed that rising age and household size contribute to resource use inefficiency in part-time food crop farming, while level of education and years of farming experience increased resource use efficiency among the sample farmers. Implications are that policies that would encourage relatively younger and educated persons and provide them easy access to improved seeds and fertilizers will go a long way in enhancing resource use efficiency in part-time food crop farming.

Key Words: Efficiency, Food crop, Part-time farming, stochastic frontier production
\end{abstract}

\section{INTRODUCTION}

In Nigeria, agriculture has primarily been a rural based occupation, engaged in by multitudes of small scale farmers characterized by small holdings ranging from 0.05 to 3.0 hectares of farm land, rudimentary farm systems, low capitalization and low yield per hectare (Kolawole and Ojo 2007). The increasing demand for food and jobs in urban and suburban areas, has made it necessary for employed wage earning urban and sub-urban dwellers to practice part-time farming as a means of filling the food demand and supply gap and providing income to supplement their wages (Amodu, 2010). The part-time food crop farmers like other farmers will typically produce to satisfy household food needs or make profit from selling or both. If the production were for household consumption, then the farmer will aim at obtaining the optimum output from his or her effort. If on the other hand, the part-time farmer produces for market to earn income to supplement wages, then the cost of production and returns accruable to the farmerôs production effort becomes an important measure of performance. Either of the two objectives of production requires efficient use of farm resources (Umoh, 2006). Efficiency is at the heart of agricultural production. This is because the scope of agricultural production can be expanded and sustained by farmers through efficient use of resources (Ali, 1996; Udoh, 2000).For this reasons, efficiency has remained an important subject of empirical investigation particularly in developing economies where majority of farmers are resource-poor (Umoh,2006).

Empirical studies on efficiency of part-time farming in Nigeria are scant and far between. Few of such studies paid particular attention to urban farming (Udoh, 2005; Umoh, 2006) with little or no attention paid to part-time food crop farming. This paper is therefore aimed at estimating the current level of resource use efficiency among part-time food crop farmers in the study area. The specific objectives of the study are to:

(i) establish the cropping pattern and farm size distribution in the study area;

(ii) measure the costs of and return to part-time food crop farming and the profitability of parttime food crop farming in the study area;

(iii) establish the determinants of farm output in part-time food crop farming in the study area; and

(iv) establish the socio-economic determinants of resource use efficiency in part-time food crop farming in the study area. 
Theoretical framework: The concept of efficiency is concerned with the relative performance of the process of transforming inputs to outputs. Three types of efficiency are identified in literature. These are technical, allocative and economic efficiency (Farrell, 1957, Olayide and Heady, 1982). Bhasin (2002) defined technical efficiency as the ability of the farmer to obtain maximum output for a given set of inputs under a given technology. Allocative efficiency is a measure of the degree of success in achieving the best combination of different inputs in producing a specific level of output considering the relative prices of the inputs (Umoh, 2006). Economic efficiency is a product of technical and allocative efficiency (Olayide and Heady, 1982).

Following the seminal work of Farrell (1957), several empirical studies have been conducted on farm efficiency. These studies have employed several measures of efficiency. These measures have been classified broadly into three namely: i) deterministic parametric estimation ii) nonparametric mathematical programming and iii) the stochastic parametric estimation (Umoh, 2006). There are two non- parametric measures of efficiency known in literature. The first based on the work of Chava and Aliber (1983) and Chava and Cox (1988) evaluates efficiency based on the neoclassical theories of consistency, restriction of production form, recoverability and extrapolation without maintaining any hypothesis of function forms. The second by Farrell (1957) decomposed efficiency into technical and allocative. Both the parametric and nonïparametric methods have been used in empirical studies of farm efficiency in several approaches. These include; the production functions, programming technique and recently the efficiency frontier. The frontier is concerned with the concept of maximality in which the function sets a limit to the range of possible observations (Forsund et al., 1980). Thus, it is possible to observe points below the production frontier for firms producing less than the maximum possible output but, no point can lie above the production frontier, given the technology available. The frontier represents, therefore an efficient technology and any variation from it is considered inefficient.

The stochastic frontier modeling is becoming increasingly popular among production economists because of its flexibility and the ease with which it can be used to relate economic concepts in modeling reality (Kolawole and Ojo, 2007). And based on this the model is employed in this paper to provide a basis for estimating farmlevel resource use efficiency. The stochastic frontier production model of Cobb-Douglas functional form is employed to estimate the farmlevel resource use efficiency. The Cobb-Douglas functional form is widely used in farm efficiency studies in developed and developing countries and it meets the requirement of being self-dual, allowing an examination of economic efficiency (Kolawole and Ojo, 2007).

The stochastic frontier production function is typically specified as follows:

$\mathrm{Yi}=f\left(\mathrm{x}_{\mathrm{ij}} ; \mathrm{b}\right)+\mathrm{v}_{\mathrm{i}}-\mathrm{u}_{\mathrm{i}}(\mathrm{i}=1,2, \mathrm{n}$

$\mathrm{Yi}=$ Output of the $\mathrm{i}^{\text {th }}$ firm;

$X_{i j}=$ Vector of actual $j^{\text {th }}$ input used by $\mathrm{i}^{\text {th }}$ farm;

$\mathrm{b}=$ Vector of production coefficients to be estimated

$\mathrm{v}_{\mathrm{i}}=$ Random variability in the production that cannot be influenced by the farmer.

$\mathrm{u}_{\mathrm{i}}=$ Deviation from maximum potential output attributable to resource use inefficiency.

The model is such that the possible production $Y_{i}$, is bounded above by the stochastic quantity $f\left(\mathrm{x}_{\mathrm{i}}, 6\right) \exp \left(\mathrm{v}_{\mathrm{i}}\right)$ when $\mathrm{u}_{\mathrm{i}}=0$ hence the term stochastic frontier.

Direct estimates of the parameters can be obtained by either the Maximum Likelihood Method (MLM) or the Corrected Ordinary Least Squares method (COLS). However, the MLM estimator has been found to be asymptotically more efficient than the COLS (Coelli, 1995).

In the context of the stochastic frontier production function, the technical efficiency of a firm is defined as the ratio of the observed output to the corresponding frontier output conditional on the levels of inputs used by the firm. Thus the technical efficiency of the firm is defined as:

$\mathrm{Te}_{\mathrm{i}}=\mathrm{Y}_{\mathrm{i}} / \mathrm{Y}^{*}=\exp \left(\mathrm{v}_{\mathrm{i}}-\mathrm{u}_{\mathrm{i}}\right) / \exp \left(\mathrm{v}_{\mathrm{i}}\right)=\exp \left(-\mathrm{u}_{\mathrm{i}}\right)$

Where, $\mathrm{Te}_{\mathrm{i}}=$ Technical efficiency of farmer $i$

$\mathrm{Y}_{\mathrm{i}}=$ Observed output from farm $i$ and

$\mathrm{Y}^{*}=$ Frontier out put

$\mathrm{Te}_{\mathrm{i}}$ ranges between 0 and 1 . Maximum efficiency has a value of 1.0. Lower value represent less than maximum efficiency in production.

The use of stochastic frontier analysis in studies in agriculture in Nigeria is a recent development. 
Such studies include; Ojo (2004), Umoh (2006), Kolawole and Ojo (2007), Oji and Chukwuma (2007) and Amodu (2010). Available literature indicates that part-time farming in Nigeria is yet to benefit significantly from application of the stochastic frontier model. Therefore, the model will be applied for the purpose of estimating the efficiency of resource use by part-time food crop farmers in the study area.

\section{RESEARCH METHODOLOGY}

Study Area: The study is based on farm level data collected from part-time farmers in Idah Local Government Area of Kogi State, Nigeria. Located in the eastern senatorial district of the State, Idah LGA is bounded on the east and north by Igallamella Odolu LGA, on the south by Ibaji LGA and on the east by Etsako L.G.A of Edo state from which it is bounded by the River Niger. Idah is the smallest of the 21 LGAs in Kogi state in terms of land mass and Igala is the language predominantly spoken by the people. Kogi State is located in North Central Nigeria and is a predominantly agrarian state.

The topography of Idah is undulating plains at elevation ranging from 150 meters to 300 meters. It has massive sand and clay soil which provide suitable medium for all crops. This varies from the alluvial plains of the river side to the lateritic sandy loam soils of the hinterland. Rainy season in Idah is between April and October with annual rainfall between $900 \mathrm{~mm}$ and $1200 \mathrm{~mm}$ and average rainy days of between 210 and 220 days per annum. Humidity is high between $70 \%$ and $90 \%$ and an average annual temperature of $27^{\circ} \mathrm{C}$ (ADP, 2002).

The vegetation is of the southern guinea savannah on the northern belt with traces of tropical forest in the southern belt. Although the original vegetation has largely been reduced by continuous cultivation and bush burning, large areas of forest reserve can still be seen. A wide range of crops and wood plants grow here under rain fed cultivation. Fadama farming in the dry season takes place along the river basins. Agriculture forms the principle means of livelihood of $80 \%$ of the population (Idachaba, 2005). Farming is the traditional occupation with emphasis on food grains such as maize, sorghum, rice and millet as well as tuber crops like yam, cassava and sweet potatoes. They also keep livestock such as sheep, goat, pigs as well as poultry and also engage in artisanal fishing. Idah LGA currently has four daily markets and a weekly market in Idah town. In all the markets, agricultural produce are the major items of trade. There are three major occupations in Idah LGA; civil service, business/trading and farming. These three are intertwined as most inhabitants who are non fulltime farmers also farm, on part-time.

Sampling Design and Data Collection Procedure: Multi-stage sampling technique was employed in selecting respondents. The sampling universe was made up of all wage earning employees of government and the catholic mission in the Local Government Area. This is to eliminate ambiguity in the determination of the part-time farmers in the Local Government Area. The first stage was the purposive selection of wage earning employees of government and the catholic mission who constitute the dominant employers in the study area according to employer i.e.; Federal, State, Local Government and Catholic Mission. The second stage involved a random selection of a disproportionate number of respondents from each place of employment based on the population of employees made available to the researcher. 53 were drawn from the Federal Polytechnic Idah, 30 from the State Civil Service, 45 from the Local Government Service and 22 from the Catholic Diocesan Development Services (DDS), making a total of 150 respondents.150 questionnaires were administered out of which 136 were returned by respondents. Out of the 136 respondents, $110(81.0 \%)$ indicated that they were involved in part-time food crop farming while 26 respondents $(19 \%)$ were not engaged in part-time farming. Further discussion is based on data obtained from the 110 respondent part-time food crop farmers.

Primary data were collected using structured questionnaires. The questions were structured to elicit answers on the objectives of study. The questionnaire was also designed to capture the number of respondents engaged in part-time farming. The data collected include; the socioeconomic characteristics (age, educational status, household size, farming experience, non-farm income and farm size), production variables which include; types of crop produced, inputs used including quantity and unit prices, output produced in quantity and unit price, level of 
household consumption of output and farm income.

Methods of Data Analysis: Data collected were subjected to the following tools of analysis; Descriptive Statistics consisting of; simple percentages and proportions, mean and standard deviation; Gross Margin Analysis, was used to estimate the cost and returns in part-time food crop farming. It is given as:

GM $=$ TR-TVC

Where; GM = Gross Margin (

TR $=$ Total revenue $(\mathbb{N})$

TVC $=$ Total variable cost $($ the cost of variable inputs) (

Olukosi and Erhabor (1988) maintained that gross margin is a good approximation of net farm income, since small-scale farmers usually have negligible fixed costs.

Revenue was calculated on the basis of the following average values: Maize: yield; 2 tons per ha@N35,000/ton, Yam: 7000 tubers/ha @N20 per tuber, Cassava: 24 sacks of 100kg @ N1, 500/sack; cuttings: bundles of $200 @$ N100/bundle. The variable cost was calculated using the market value of the purchased inputs, including labour, tractor usage and other operating expenses i.e the quantity used multiplied by the prevailing input price.

The Stochastic Frontier Production Function: This was used to estimate the technical efficiency of part-time food crop farming. The model used in this study is based on the one proposed by Battese and Coelli (1995) in which the stochastic frontier specification incorporates models for the technical inefficiencies effects and simultaneously estimate all the parameters involved in the production function models. The production technology of the part-time food crop farmers was assumed as specified by the Cobb-Douglas frontier production function which is defined as:

$\operatorname{Ln} Y_{i}=\operatorname{Ln}_{0}+\times \sigma_{j} \operatorname{LnX} X_{i j}+v_{i} i ̈ \mu_{i}$

Where;

$\mathrm{Y}_{\mathrm{i}}=$ Total value of farm output (in Naira) from $\mathrm{i}^{\text {th }}$ farm. $; \mathrm{X}_{1}=$ Farm size in hectares $; \mathrm{X}_{2}=$ Labor used (in Mandays).

$\mathrm{X}_{3}=$ Seeds/planting materials in kilograms; $\mathrm{X}_{4}=$ Quantity of Fertilizers used in kilograms;
$\mathrm{X}_{5}=$ Tractor usage (in tractor-hours); $\mathrm{b}_{0}=$ Intercept $; \mathrm{\sigma}_{\mathrm{ij}}$ $=$ Vector of production function parameters to be estimated, i=1, 2, 3,é ,n farms ; $\mathrm{j}=1,2,3$,é ,m inputs.

$\mathrm{v}_{\mathrm{i}}=$ Random variability in the production that cannot be influenced by the farmer.

$\mu_{\mathrm{i}}=$ the deviation from maximum potential output attributable to resource use inefficiency.

The technical inefficiency affect $\boldsymbol{\mu}_{\mathbf{i}}$ is defined by:

$\mu_{\mathrm{i}}=\delta_{0}+\delta_{1} \mathrm{Z}_{1 \mathrm{i}}+\delta_{2} \mathrm{Z}_{2 \mathrm{i}}+\delta_{3} \mathrm{Z}_{3 \mathrm{i}}+\delta_{4} \mathrm{Z}_{4 \mathrm{i}}$

$\mu_{\mathrm{i}}=$ resource use/technical inefficiency effect of the $i^{i}$ th farm

Where; $Z_{1}, Z_{2}, Z_{3}$, and $Z_{4}$ respectively are; age of the farmer, educational level, household size, and farming experience. These are included in the model to indicate their possible influence on the technical efficiencies of the part-time farmers.

The $\delta$ and $\delta$ are unknown parameters to be estimated along with the variance parameters $\delta^{2}$ and $\boldsymbol{\gamma}$.

The variance of the random error $\delta \mathrm{v}^{2}$ and that of the technical inefficiency effect $\delta^{2} u$ and the overall variance of the model are related as follows:

$\delta^{2}=\delta v^{2}+\delta u^{2}$

$\gamma=\delta \mathrm{u}^{2} / \delta^{2}$

Equation (6) measures the total variation of production (output) from the frontier which can be attributed to resource use/technical inefficiency (Battese and Corra, 1977). The $\delta^{2}$ and $\gamma$, coefficients are the diagnostic statistics that indicate the relevance of the use of the stochastic frontier function and the correctness of the assumptions made on the distribution form of the error term.

The $\delta^{2}$ indicates the goodness of fit and the correctness of the distributional form assumed for the composite error term. The $\gamma$, indicates that the systematic influences that are unexplained by the production and cost function are the dominant sources of random errors. The statistical significance of these shows the presence of onesided error component, $\mathrm{v}_{\mathrm{i}}$ in the model specified. Because of the presence of this one-sided error component, the traditional response function estimated by the ordinary least square cannot adequately represent the data, hence the use of the stochastic frontier function estimated by the Maximum Likelihood Estimation procedure. 
The estimates for all the parameters of the stochastic frontier function and the inefficiency model are simultaneously obtained by the maximum likelihood estimation method using the program FRONTIER version 4.1c (Coelli, 1996).

\section{RESULTS AND DISCUSSION}

Cropping Pattern and Farm Size Distribution: The study revealed the sample part-time farmers cultivated between 0.5 ha and a maximum of 5 ha. The crops grown varied widely but the most economically significant from the perspective of the farmers are the crops shown in Table1.

Table1: Dominant Crops Grown by Part-time Food Crop Farmers and Average Area Cultivated

\begin{tabular}{|c|c|c|c|}
\hline $\begin{array}{l}\text { Crop } \\
\text { Grown }\end{array}$ & $\begin{array}{c}\text { No of } \\
\text { Farmers }\end{array}$ & $\%$ & $\begin{array}{l}\text { Average Farm } \\
\text { Size (Ha) }\end{array}$ \\
\hline Maize & 80 & 73 & 1.30 \\
\hline Yam & 30 & 27 & 0.50 \\
\hline Cassava & 110 & 100 & 1.80 \\
\hline
\end{tabular}

The main crops grown by the part-time farmers are maize, cassava, and yams. The generally adduced reason for growing these crops is the commercial value they are able to derive from selling, particularly maize and yams. Farmers in the study area, practice split plot mono-cropping. They usually cultivate these crops on various plots of farm land in different locations. The study revealed that about $73 \%$ of the part ï time farmers cultivated maize in season and about $27 \%$ of the parttime farmers grow yam. All the partï time farmers own cassava farms because of the ease with which it can be farmed.

Cost and Returns to Part-Time Farming: The part-time farmers were mostly small scale farmers (Amodu, 2010). Their costs were dominated by variable costs which include; cost of seed, fertilizer, labour, land preparation and cost of on-farm processing and transportation. Most of the part-time farmers cultivate three dominant sole crops on split plots per season. The average prevailing market prices of the various crops harvested were used to derive the gross farm revenue or the total value of production.

The gross margin analysis based on the three dominant enterprises produced by part-time food crop farmers in the study area is shown in Table 2. The study reveals that yam has the highest gross margin followed by maize and cassava with $\$ 64,465.67, \$ 41,180.78$ and N40,085.32 respectively. Labour was the highest variable cost item while land preparation was the lowest. The average gross margin for part-time farming in the study area comes to $\$ 48,577.26$.

Table2: Analysis of Costs, Gross Margin (GM) and GM/ in Part-time Food Crop Farming.

\begin{tabular}{llll}
\hline Cost Items(Naira) & Farm & Enterprises & Produced \\
\hline Gross Margin Analysis & Maize & Yam & Cassava \\
Land preparation & $1,622.50$ & $4,960.33$ & $1,323.08$ \\
Labour & $19,965.62$ & $50,859.00$ & $10,646.00$ \\
Planting materials & $2,283.10$ & $16,705.50$ & $2,141.10$ \\
Fertilizer & $2,940.50$ & $8,821.50$ & - \\
Other operating expenses & 2007.50 & $9,218.00$ & $1,804.50$ \\
Variable Costs(1) & $28,819.22$ & $75,534.33$ & $15,914.68$ \\
Revenue(2) & $70,000.00$ & $140,000.00$ & $56,000.00$ \\
Gross Margin(2-1) & $41,180.78$ & $64,465.67$ & $40,085.32$ \\
Gross margin/Naira invested & 1.43 & 0.85 & 2.52 \\
\hline
\end{tabular}

The gross margin per Naira invested showed that cassava has the highest return followed by maize and yam with returns of 2.52,1.43 and 0.85 respectively. Profitability analysis shows that for every Naira invested, the part-time food crop farmer earns revenue of N1.60 on the average, which is quite profitable compared to the current bank interest rate on savings put at $10 \%$ per annum on the average (Amodu, 2010). 
Table 3: Maximum Likelihood Estimates of the Stochastic Frontier Production Function

\begin{tabular}{|c|c|c|}
\hline Variable & Parameters & Coefficient \\
\hline \multicolumn{3}{|l|}{ Production model: } \\
\hline Constant & $\mathrm{b}_{0}$ & $\begin{array}{l}10.64 * \\
(95.73)\end{array}$ \\
\hline Farm size & $b_{1}$ & $\begin{array}{c}0.447 * \\
(5.78)\end{array}$ \\
\hline Labour & $b_{2}$ & $\begin{array}{l}0.363^{*} \\
(10.44)\end{array}$ \\
\hline Planting materials & $\mathrm{b}_{3}$ & $\begin{array}{l}0.062 * \\
(1.73)\end{array}$ \\
\hline Fertilizer & $\mathrm{b}_{4}$ & $\begin{array}{l}0.022^{\mathrm{NS}} \\
(0.41)\end{array}$ \\
\hline Tractor use & $6_{5}$ & $\begin{array}{l}0.058^{\mathrm{NS}} \\
(0.58)\end{array}$ \\
\hline \multicolumn{3}{|l|}{ Inefficiency model ${ }^{+}$: } \\
\hline Constant & 80 & $\begin{array}{l}1.94^{*} \\
(1.78)\end{array}$ \\
\hline Age & $\delta 1$ & $\begin{array}{l}0.024^{\mathrm{NS}} \\
(1.42)\end{array}$ \\
\hline Education & 82 & $\begin{array}{l}-0.109 * \\
(-5.93)\end{array}$ \\
\hline Household & 83 & $\begin{array}{l}0.24 * \\
(2.29)\end{array}$ \\
\hline $\begin{array}{l}\text { Farming Experience } \\
\text { Variances: }\end{array}$ & 84 & $\begin{array}{l}-0.23^{*} \\
(-6.44)\end{array}$ \\
\hline Sigma square & $\sigma 2$ & $\begin{array}{l}1.14^{*} \\
(10.55)\end{array}$ \\
\hline Gamma & $y$ & $\begin{array}{l}0.99 * \\
(47.45)\end{array}$ \\
\hline $\begin{array}{l}\text { Log likelihood } \\
\text { function }\end{array}$ & $\begin{array}{l}\text { Llf } \\
\text { LR test }\end{array}$ & $\begin{array}{l}-5.4 \\
20.95 \\
\end{array}$ \\
\hline $\begin{array}{l}\text { Figures in parenthesi } \\
\text { significant at } 5 \% \text { level at } \\
\text { NS indicates not signific } \\
+ \text { A negative sign on a } \\
\text { impact on efficiency. }\end{array}$ & $\begin{array}{l}\text { are t-ratio. } \\
\text { below. } \\
\text { t @ 5\% level. } \\
\text { arameter indica }\end{array}$ & $\begin{array}{l}\text { Estimate is } \\
\text { es a positive }\end{array}$ \\
\hline
\end{tabular}

\section{Productivity and Technical Efficiency:} Maximum Likelihood Estimates of the stochastic frontier production function for part-time farmers in the study area are presented in Table 3.

The variance parameter estimate for sigma squared $\left(\sigma^{2}\right)$ and gamma $(\gamma)$ are 1.14 and 0.99 respectively. They are significant at the $1 \%$ level. The sigma squared $\sigma^{2}$ indicates the goodness of fit and correctness of the distributional form assumed for the composite error term while the gamma $\gamma$ indicates the systematic influences that are unexplained by the production function and the dominant sources of random error. This means that the inefficiency effects make significant contribution to the technical efficiencies of parttime farmers. The estimated gamma $\gamma$ parameter of 0.99 indicates that about $99 \%$ of the variation in the value of farm output of part-time farmers was due to differences in their technical efficiencies. Thus, the hypothesis that the parameter estimate of $\gamma=0$ is rejected. The result shows that inefficiency effects were present and significant. This was confirmed by the test of hypothesis using the Log Ratio Test. The Log Ratio (LR) test is 20.95 while the critical value of the chi-square at 5\% level of significance with 6 degrees of freedom $\chi^{2}(5 \%, 6)$ was 12.60 .

The estimated coefficients of all the parameters of production function are positive. The total value of farm output increases by the value of each of the positive coefficients as the value of each variable increases by unity. The result of the stochastic frontier production function model is discussed as follows;

Farm size $\left(\boldsymbol{\beta}_{1}\right)$ : The coefficient of farm size was found to be positive and significant at $5 \%$ level. The result is in line with the findings of Umoh (2006) study of urban farming in south-south Nigeria and Okike (2000) study of farmers in the savanna zone of Nigeria. They both reported farm size to be significant and positive. The result could mean that it is possible to expand farming activity in the study area. Statistically, the magnitude of the coefficient of farm size show that total value of farm output is inelastic to land area cultivated. If farm size is increased by $10 \%$, total value of farm output level will improve by less than proportionate margin of $4.47 \%$. This means that there is still some scope for increasing the value of farm output per plot by expanding the land area cultivated.

Labour ( $\left.\boldsymbol{\beta}_{2}\right)$ : The coefficient of labour was significant and had a positive sign. This shows the importance of labour in part-time food crop farming in the study area. This is in line with several studies that have confirmed the importance of labour in farming. Studies by Umoh (2006) and Okike (2000) have shown the importance of labour in farming, particularly in developing countries where mechanization is rare on small scale farms. In the study area, human power plays a crucial role in virtually all farming activities. This situation has variously been attributed to the 
practice of split-plot cropping on small scattered land holdings and the lack of affordable equipment (Umoh and Yusuf, 1997; Amodu, 2010). It appears that labour will continue to play important role in part-time food crop farming, affecting its efficiency, until those factors constraining mechanization are removed. The magnitude of the coefficient of labour shows that total value of farm output is inelastic to the level of labour used. If labour is increased by $10 \%$, value of farm output will improve marginally by $3.36 \%$. The implication of this is that the total value of farm output can be increased by employing more labour.

Planting materials $\left(\boldsymbol{\beta}_{3}\right)$ : The coefficient of planting materials was positive and significant at 5\% level. This implies that planting materials are important in crop production in part-time farming. If planting materials are increased by $10 \%$, value of farm output will only increase by $0.62 \%$. The implication of this is that the value of farm output is highly inelastic to planting materials and farm output cannot be significantly increased by increasing the use of planting materials.

Fertilizer $\left(\boldsymbol{\beta}_{4}\right)$ : The production elasticity with respect to fertilizer is 0.022 . By increasing the quantity of fertilizer by $10 \%$ value of farm output will only increase by $0.22 \%$. The estimated coefficient of fertilizer is positive but not significantly different from zero. This finding is at variance with Umoh (2006). In his study of urban farming, he found the coefficient of fertilizer to be highly significant at $1 \%$ level. However, the study shows that fertilizer was not significant at 5\% level in line with Amodu (2010).

Tractor use $\left(\boldsymbol{\beta}_{5}\right)$ : The coefficient of tractor use is positive but not significantly different from zero. The production elasticity of tractor use is 0.058 , implying that a $10 \%$ increase in tractor use will only lead to $0.58 \%$ increase in the value of farm output. The high inelasticity of tractor use in parttime farming in the study area could be due to small farm sizes operated by the farmers.

Technical Inefficiency Model: Analysis of the inefficiency model contained in Table 5 shows that the signs and significance of the estimated parameter coefficients in the inefficiency model have important implications on the resource use efficiency of part-time food crop farmers in the study area. The contribution of part-time food crop farmersô personal characteristics; age, level of education, household size and farming experience to resource use efficiency were studied. The variables of the inefficiency model are discussed as follows;

Age ( $\delta 1)$ : The coefficient of age of part-time farmers is positively related to inefficiency and not significantly different from zero at $5 \%$ level of significance. The implication of this is that age contributes to resource use inefficiency in parttime food crop farming in the study area. The effect of age on the efficiency of the part-time food crop farmers may be due to declining productivity on the farm. This finding is in agreement with Kolawole and Ojo(2007) who in their study of small scale farmers in Nigeria found age to be positively related to inefficiency. However, Umoh (2006) in his study of urban farming found age not contributing to farm inefficiency.

Education $(\boldsymbol{\delta} 2)$ : The coefficient of level of education is negatively related to inefficiency and significant at 5\% level of significance. The implication of this is that inefficiency of resource use in part-time food crop farming in the study area decreases with the level of education. The likely implication of this is that the more educated the part-time farmers are the more attention they pay to effective management of their farms.

Household size ( $\delta 3)$ : The coefficient of household size in the inefficiency model is positive and significantly different from zero at 5 $\%$ level of significance. The implication of the positive coefficient of household size is that it contributes to resource use inefficiency in parttime food crop farming in the study area. The effect of household size on farm level resource use efficiency is traceable to its use as a source of labour supply for work on the farm. In some instances family labour may be forced resulting in drudgery and poor workmanship.

Farming experience ( 84$)$ : Farming experience of the part-time food crop farmers in the inefficiency model is negative and significant at $5 \%$ level of significance. The negative coefficient of farming experience indicates that it contributes to increased resource use efficiency in part-time food crop farming. The implication of this is that the more experienced the part-time food crop farmers 
are the more effective they are in the operation of their farms.

The significant inefficiency variables shown in Table 3 are; education, household size and farming experience at $1 \%$ level of significance. These finding are in agreement with earlier findings by Ajibefun and Daramola (2003); Ojo (2004); Kolawole and Ojo (2007) who in their various studies found level of education and years of farming experience as significant determinants of farm level technical efficiency.

Farm Level Technical Efficiency Scores: The frequency distribution of predictive individual farm level technical efficiency score is shown in Table 4.The table shows that over $72 \%$ of the parttime farmers in the study area have technical efficiency scores of over $50 \%$ with an average score $65 \%$

\section{CONCLUSION AND RECOMMENDATION}

This paper looked at the cropping pattern and farm size distribution, and measured the costs and returns to part-time food crop farming to establish its profitability. Stochastic frontier production function was used to estimate technical efficiency of part-time food crop farming in the study area. The result of the study shows that the sampled farmers were mostly small scale operators. The farmers grow mainly maize and cassava as sole crops on split plots. The study also revealed labour input as a major cost item in their production. Gross margin analysis shows that a part-time food crop farmer realizes an average gross margin of \# 48, 577.26 per hectare cultivated and an average of $\$ 1.60$ on every naira invested in production. Productivity analysis shows that farm size, labour and planting materials are significant determinants of farm output in part-time food crop farming. The study also revealed that rising age and household size contribute to inefficiency in resource use in part-time food crop farming, while level of education and years of farming experience increased resource use efficiency among the sample farmers.

Farm level technical efficiency scores shows that about $72 \%$ of part-time farmers had technical efficiency scores of over $50 \%$ with a mean score of $65 \%$. The maximum technical efficiency was $98.80 \%$ and the minimum was $36.58 \%$.
The findings of this study have implications for increased food production, household food security and income supplementation. The fact that part-time farming is a viable investment outlet for salary income earners makes it imperative for government to recognize the practice for accommodation in its agricultural policy formulation. The $65 \%$ level of technical efficiency shows that there is room to improve production to reach the optimum efficiency level of $100 \%$.

Implications of these findings are that policies that would encourage relatively younger and educated persons and provide them easy access to improved seeds, fertilizers and mechanization will go a long way in enhancing resource use efficiency and increased productivity in part-time food crop farming.

Table 4: Frequency Distribution of Farm Specific Efficiency Indices

\begin{tabular}{lcc}
\hline Efficiency indices (\%) & Frequency & $\mathbf{\%}$ \\
\hline $25-50$ & 30 & 27.30 \\
$51-75$ & 57 & 51.81 \\
$76-95$ & 19 & 17.27 \\
$96-100$ & 4 & 3.62 \\
Total & 110 & 100 \\
Minimum & 36.58 & \\
Maximum & 98.80 & \\
Mean & 65.00 & \\
\hline
\end{tabular}

\section{REFERENCES}

Ajibefun, I.A and Daramola A.G (2003). Efficiency of Micro- Enterprises in the Nigerian Economy. African Economic Research Consortium (AERC) Nairobi, Kenya.

Ali, M. (1996). Quantifying the Socio-economic Determinants of Sustainablae Crop Production: An Application to Wheat Cultivation in the Tarui of Nepal. J. Agric. Econ. 14: 45-60.

Amodu, M.Y. (2010). Economic Analysis of Parttime Farming in Idah, Local Government Area of Kogi State, Nigeria. M.Sc Thesis, Department of Agricultural Economics, Ahmadu Bello University, Zaria, Nigeria (Unpublished).

Battese, G.E and Corra, G.S (1977). Estimation of a Production Frontier Model with Application to the Pastoral Zone of Eastern Australia. Austr. J. Agric. Econ. 21:16a Ï 17a.

Battese, G.E. and Colli, T.J. (1995). A Model for Technical Inefficiency Effects in Stochastic 
Frontier Production for Panel Data. Empirical Econ. 20:325-345.

Bhasin,V.K. (2002). Credit Allocation and Technical Efficiency of Vegetable Growers in the Brong-Ahafo Region of Ghana. African Economic Research Consortium, Nairobi, Kenya.

Chavas, J. and M. Aliber (1983).An Analysis of Economic Efficiency in Agriculture: A Nonparametric Approach. J Agric. Res. Econ., 18:1

Chavas, J.P and Cox, T.L (1988). A Nonï Parametric Analysis of Agricultural Technology. Am. J. Agric. Econ. 70: 303-310

Coelli, T.J (1995a). Estimators and Hypothesis Tests for a Stochastic Frontier Function: A Monte Carlo Analysis. J. Prod. Anal. 6: 247268.

Coelli, T.J. (1996). A Guide to FRONTIER Version 4.1c: A Computer Program for Stochastic Frontier Production and Cost Function Estimation; Mimeo, Department of Econometrics University of New England, Armidale, NSW Australia

Farrel, M.J. (1957). The Measurement of Productive Efficiency, J. Royal Stat. Soc. 20: 253 ï 81.

Forsund, F.R, Lowell, C.A.K and Schmidt, P. (1980). A Survey of Frontier Production Functions and their Relationships to Efficiency Measurement. J. Econ. 13: 5-25.

Idachaba, F.S (2005). Rural Infrastructures in Nigeria: Basic needs of the Rural Majority.Vol.1: Main Report of Study Commissioned by the Federal Dept of Rural Dev; Ibadan, University of Ibadan Press; p.p 69.

Kogi State Agricultural Development Project (2002): Report of the Project Appraisal Team on the Performance of the First Phase. Lokoja, Kogi State.

Kolawale, O and Ojo, S.O (2007). Economic Efficiency of Small Scale Food Crop
Production in Nigeria: A Stochastic Frontier Approach. J. Social Sci. 14(2): 123 ï 130.

Oji, U.O. and Chukwuma, A.A. (2007). Technical Efficiency of Small Scale Poultryï Egg Production in Nigeria: Empirical Study of Poultry Farmers in Imo State, Nigeria. Res. $J$. Poultry Sci. 1(3-4): 16 Ï 21.

Ojo, S.O. (2004). Improved Labour Productivity and Technical Efficiency in Food Crop Production in Nigeria . Food Agric. Environ. 2(2): $227 i ̈ 231$.

Okike, I. (2000). Crop - Livestock Interaction and Economic Efficiency of Farmers in the Savanna Zone of Nigeria. Unpublished PhD Thesis, Department of Agricultural Economics, University of Ibadan, Nigeria.

Olayide, S.O. and Heady, E.O. (1982). Introduction to Agricultural Production Economics. University Press, University of Ibadan, Nigeria.

Olukosi, J.O. and Erhabor, P.O. (1988). Introduction to Farm Management Economics: Principles And Applications. Zaria AGTAB Publishers Ltd.

Udoh, E.J. (2000). Land Management and Resource Use Efficiency Among Farmers in South ï Eastern Nigeria, Unpublished $\mathrm{PhD}$ Thesis, Department of Agricultural Economics, University of Ibadan, Ibadan, Nigeria.

Udoh, E.J. (2005). Technical Inefficiency in Vegetable Farms of Humid Region: An Analysis of Dry Season Farming by Urban Women in South-South Zone, Nigeria. $J$. Agric. Soc. Sci, 1:80-85.

Umoh, G.S and Yusuf, S.A (1997). An Empirical Analysis of the Poverty Status and Productivity of Rural Farmers in Obubra, Across River State, Nigeria. The Niger. J. Econ. Soc. Stud. 41: 259 ï 274.

Umoh, G.S. (2006). Resource Use Efficiency in Urban Farming: An Application of Stochastic Frontier Production Function. Int. J. Agric. Biol., 8 (1):38 ï 44. 